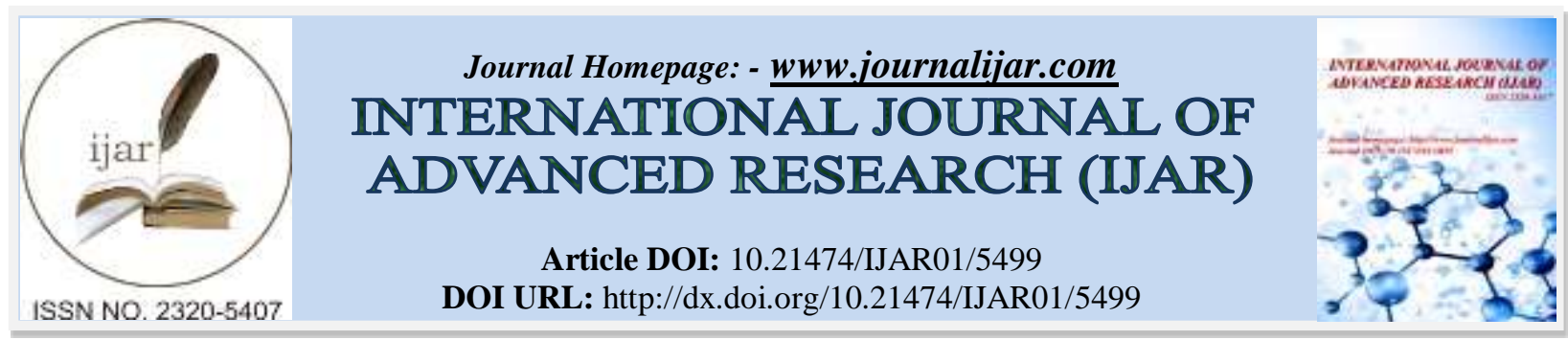

RESEARCH ARTICLE

\title{
PRODUCTION AND CHARACTERIZATION OF POROUS KAOLINITE MODIFIED PELLETS FOR SLOW RELEASE PHEROMONE.
}

\section{Monteiro ${ }^{1}$, A. Matos ${ }^{1}$, S. Aquino ${ }^{1}$, F. Gaona ${ }^{1}$, C. Schaerer ${ }^{1}$, F. Arias ${ }^{2}$, D. Dorigo ${ }^{2}$, M.C. Vega ${ }^{2}$, A. Rojas de} Arias $^{2}$, A. A. Ribeiro ${ }^{3}$ and M. Varella ${ }^{3}$.

1. Facultad Politécnica, Universidad Nacional de Asunción, San Lorenzo, Paraguay, P.O. Box 2111SL.

2. Centro para el Desarrollo de la Investigación Científica-CEDIC (FMB/Díaz Gill Medicina Laboratorial), Manduvirá 635, Asunción, Paraguay.

3. Laboratório de Tecnologia de Pós, Divisão de Processamento e Caracterização de Materiais, Instituto Nacional de Tecnologia, Av. Venezuela, 82/602, Rio de Janeiro (RJ), Brasil.

\section{Manuscript Info}

(..........................

Manuscript History

Received: 22 July 2017

Final Accepted: 24 August 2017

Published: September 2017

Key words:-

Chagas disease, triatomine control, pheromone, slow release, Triatoma infestans, matakaolinite.

\section{Abstract}

Natural and modified kaolinite minerals are widely used in industrial applications and environmental protection, in particular, sorbent processes. The aim of this work consists in proposing an alternative application for the kaolinite as a slow release device of pheromone benzaldehyde. Porous kaolinite pellets were produced by uniaxial compression molding under a pressure of $145 \mathrm{MPa}$, approximately. The pellets were sintered at $900^{\circ} \mathrm{C}$ and characterized by X-ray diffraction (XRD), Energy Dispersive X-ray fluorescence spectroscopy (EDX) and Fourier transform infrared spectroscopy (FTIR). Afterwards, these pellets were impregnated with benzaldehyde, a synthetic pheromone used to attract kissing bugs. The pellets were analyzed by FTIR, after the impregnation process, in order to verify the presence of the sorbed benzaldehyde. In addition, bioassays were performed in laboratory scale, on $T$. infestans nymphs and adults for evaluating the maximum release period and the attractant efficiency of pellets using impregnated pellets and control ones. The results of the release of benzaldehyde analysis showed existence of benzaldehyde after sixty days and the results of bioassays release showed more effectiveness in attraction of adult insects than nymph instars, suggesting that the porous kaolinite pellets are a promising alternative in trap system applications in the vector control to $T$. infestans, using benzaldehyde.

Copy Right, IJAR, 2017. All rights reserved.

\section{Introduction:-}

Kaolinite minerals have been used widely in structural, electronic and optical applications (1), zeolite production (2), ceramic foams (3), as adsorbent (4), and others. Kaolinite is used, particularly, in the field of adsorbents due to the excellent property that water or other molecules adsorb up in the interlamellar space $(5,6,7)$. The absorbency capacity of kaolinite strongly depends on their composition and morphology. Kaolinite minerals can be modified by thermal treatment and the organic groups can be attached to them by chemical bonding, adsorption or absorption (8). 
Sex pheromones are powerful chemical attractants emitted by female and male insects. Pheromones of many species have been identified and are synthetically produced for use in pest management programs. Aggregation pheromones are other type of pheromone produced by either or both sexes to attract males and females to food and harborage. Benzaldehyde $\left(\mathrm{C}_{6} \mathrm{H}_{5} \mathrm{CHO}\right)$ is the simplest and most used industrially of the aromatic aldehydes. It is widely used in flavors such as almond and cherry in various fragrances for soaps and toiletries, in the pharmaceutical production, aromatic alcohols, photographic chemicals and others (9). In the context of using by its aromatic property, Torto et al. (10) reported the application of benzaldehyde and five others aromatic compounds as aggregation pheromone system to young and older adult gregarious desert locust Schistocerca gragaria. Leal et al. (11) reported the application of benzaldehyde as alarm pheromone to the acarid mite Tyrophagus perniciosus. Previous studies carried out have found that benzaldehyde is liberated as volatile pheromone during triatomine copulation (12).

Currently, different countries in South America, including Paraguay, Brazil and Argentina, have been developing programs to eliminate Chagas disease vectors and monitor their reinfestation process through surveillance entomological systems. One of the potential methods that are being experimentally tested consists in using polyethylene bags, which store a substance (pheromone) to attract the vector (kissing bugs or triatomines). According to Rojas de Arias et al. (13), release rates of hexanal and benzaldehyde from polyethylene vials remain only 20 days at room temperature. This rapid evaporation of the attractive substance constitutes the main disadvantage of using this strategy of release, since when the technique is being tested in a season, control activities are carried out at one, three and six months of post-spraying. The strategy loses efficiency after 20 days, and consequently it demands a lot of financial support for recharging the attractive substance in all the places that are being monitored.

The aim of this work is to study the possibility of the porous kaolinite pellets to be applied as a slow release system of pheromone, for trapping of Chagas disease vectors, using the benzaldehyde as attractant substance. The results demonstrate that the present system is very efficient, since it can be used for longer time and is more efficient during the assays (bioassays) using kissing bugs (males, females and nymphs), separately.

\section{Materials and methods:-}

\section{Porous Pellet Preparation.}

The commercial kaolinite (INNAT) powder was used to prepare porous pellets. The powder was manually mixed with $20 \% \mathrm{w} / \mathrm{w}$ of porogenic agent (cornstarch), both with granulometric range $p<53 \mu \mathrm{m}$, and uniaxially compacted at $148 \mathrm{MPa}$, using a cylindrical die of $20 \mathrm{~mm}$ in diameter. Pellets were sintered in air at $900^{\circ} \mathrm{C}(\mathrm{M} 2 \mathrm{CA})$ for $6 \mathrm{~h}$ with a heating rate of $10^{\circ} \mathrm{C} / \mathrm{min}$ and then they were cooled down until room temperature (14).

The chemical composition was determined by Energy Dispersive X-ray fluorescence spectrometer, model EDX-720. A Panalytical with cobalt pipe, model XPERT Pro MPD, using $40 \mathrm{~mA}$ and $40 \mathrm{kV}$, was used to record X-ray diffraction patterns at a resolution of $10^{\circ}$ to $55^{\circ}$ with $0.02^{\circ}$ steps and counting time at $1 \mathrm{~s}$.

Fourier Transform Infrared Spectroscopy (FTIR) analyses were performed in a Nicolet 800 spectrometer associated with an Mtech PAS cell. FTIR spectra were obtained in 4000-400 $\mathrm{cm}^{-1}$ interval with 128 scans at a wavenumber resolution of $4 \mathrm{~cm}^{-1}$. The sample chamber of the PAS cell was purged with helium gas and dried employing magnesium perchlorate as a dehumidifying agent. The powders were mixed in $\mathrm{KBr}$, compressed into tablets and analyzed by transmittance technique. This enabled the characterization of the peculiar functional groups of the samples and to study the interaction between benzaldehyde and kaolinite pellets in different times.

The pellets were impregnated with $200 \mu \mathrm{l}$ of benzaldehyde (ANEDRA, 99.0\%, Argentine) without further purification. The release assays of benzaldehyde from kaolinite pellets were performed for 0, 24, 168, 360 and 900 hours and monitored by FTIR analyses.

\section{Triatomine bioassays.}

Twelve insects of each sex or stage were subjected separately to capture tests using pellets with and without benzaldehyde, called bioassays, each group of insects were tested sequentially for 34 and 100 days, by each assay time. The pellets were installed inside the trap boxes. These boxes were fixed one at each end of the maze, at one end a box with impregnated pellet and in another one pellet without benzaldehyde, considered as control box. The maze was internally divided into three rooms, with two internal walls and two small doors at the bottom of these walls, to allow the insects to freely move in the interior of the maze, Fig. 1. The specimens were introduced through 
an entrance at the top of the maze. The runs were performed under conditions of partial darkness during the day and total darkness at night. The bioassays were performed at room temperature and catch records were registered every two days.
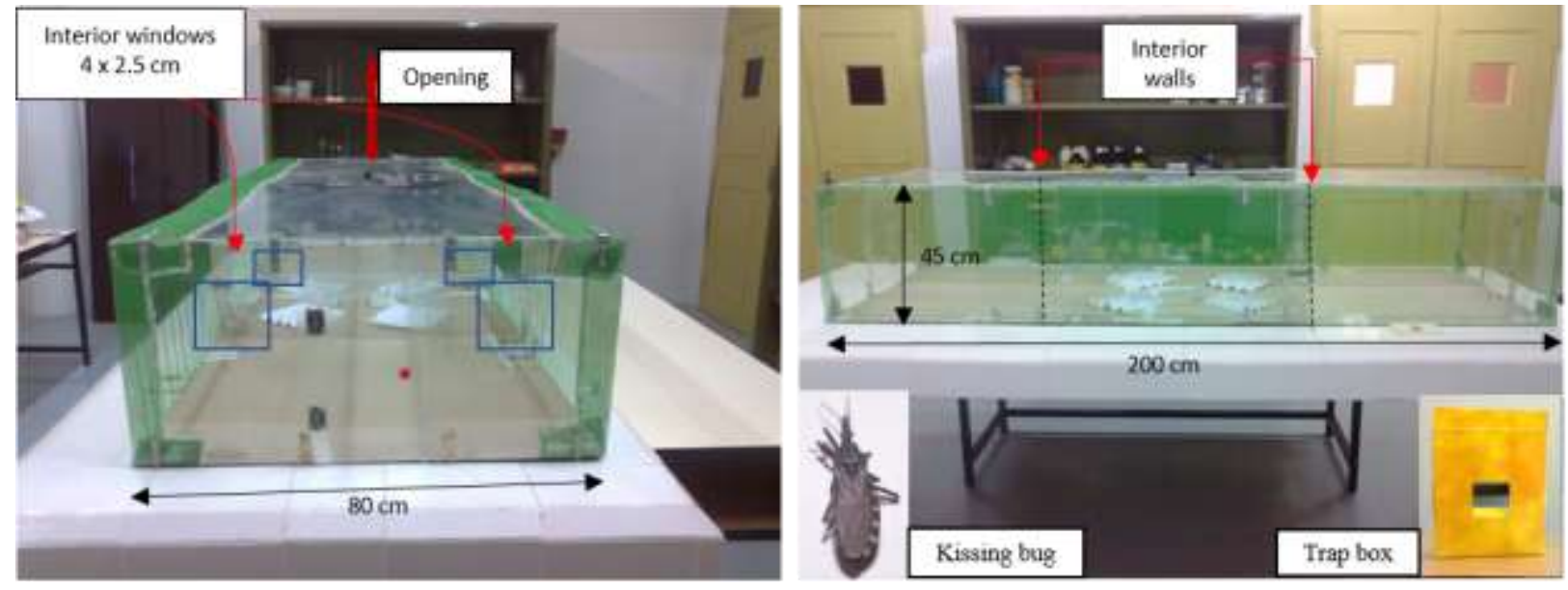

Figure 1:- Configuration of the maze indicating the dimensions and the input of the bugs, trap box $(10 \times 20 \mathrm{~cm})$ and the kissing bug.

\section{Results and discussion:-}

Kaolinite pellets characterization

EDX results of kaolinite (INNAT) and M2CA samples are shown in Table 1. Both samples presented similar chemical composition with slight variation after sintering process.

Table 1:- EDX results: chemical composition (wt $\%$ ) of INNAT and M2CA samples.

\begin{tabular}{|c|c|c|c|c|c|}
\hline \multirow{2}{*}{ Sample } & \multicolumn{5}{|c|}{ Elements (\%) } \\
\cline { 2 - 6 } & $\mathrm{SiO}_{2}$ & $\mathrm{Al}_{2} \mathrm{O}_{3}$ & $\mathrm{Fe}_{2} \mathrm{O}_{3}$ & $\mathrm{~K}_{2} \mathrm{O}$ & $\mathrm{TiO}_{2}$ \\
\hline INNAT & 53.7 & 16.7 & 18.2 & 6.9 & 3.4 \\
\hline M2CA & 52.5 & 22.5 & 12.0 & 9.0 & 3.9 \\
\hline
\end{tabular}

Figure 2 shows the X-ray diffractograms of INNAT and M2CA samples. From the XRD patterns, it can be seen the change in crystalline phases of kaolinite induced by thermal treatment to metakaolinite. Characteristic major kaolinite were absent or reduced at $2 \theta$ equal 12.49 and $25.00^{\circ}$, indicating a major loss of hydroxyl groups. The peaks at $20.80,26.78$ and $50.29^{\circ}$ correspond to quartz. Kaolinite undergoes a structural rearrangement upon heating, the calcination step causes the liberation of the hydroxyls in the form of water vapor and a more amorphous phase is formed (4). 


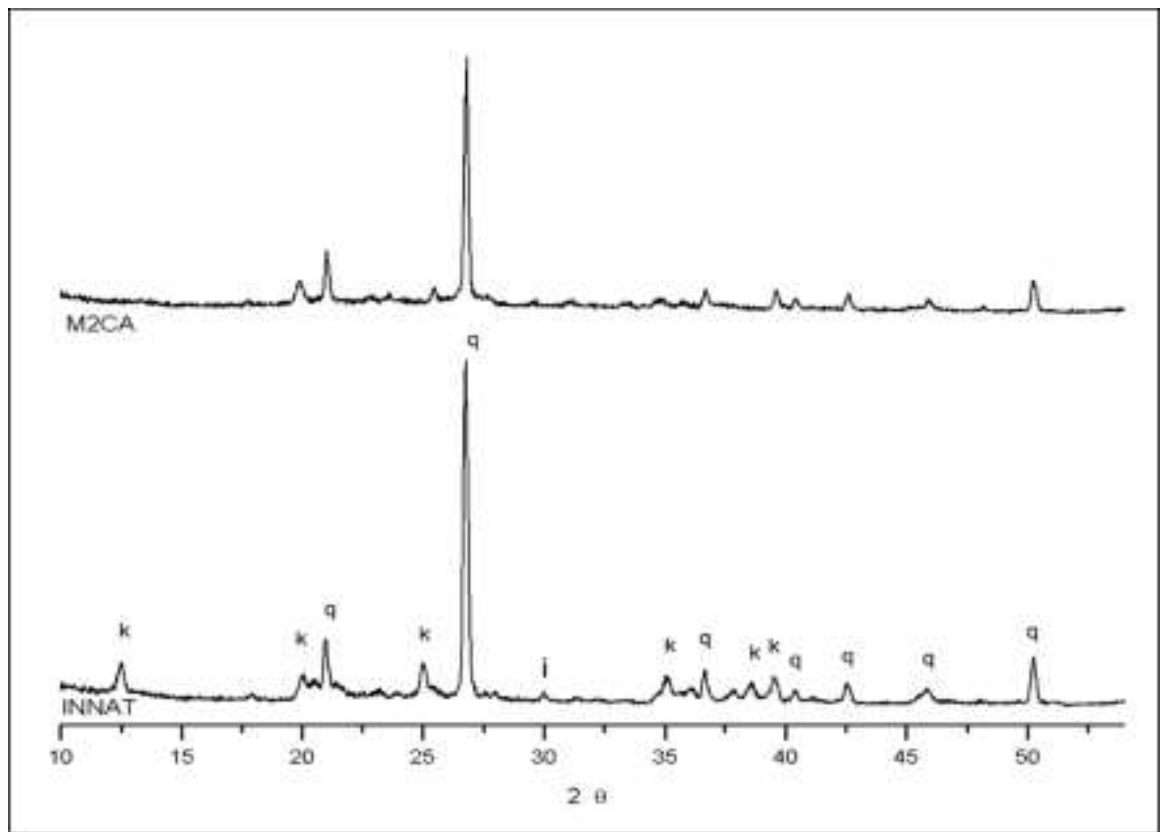

Figure 2:- X-ray diffraction patterns of INNAT and M2CA samples (k-kaolinite; q-quartz; i-illite).

FTIR spectra and band positions with their respective bond vibrations are displayed in Fig. 3 and Table 2 , respectively. Both samples showed similar absorption bands in their respective spectra. The INNAT sample presented three characteristic bands of kaolinite at 3695, 3652 and $3620 \mathrm{~cm}^{-1}$, suggesting Al-OH stretching mode. However, for M2CA sample, these bands underwent a significant absorption reduction due to the dihydroxylation, as evidenced by the bands at 3651 and $3476 \mathrm{~cm}^{-1}(15,16,17)$. H-O-H bending vibrations of water exhibited absorption bands at 1637 and $1629 \mathrm{~cm}^{-1}$. The absorption at 1114 and $912 \mathrm{~cm}^{-1}$ in the INNAT sample spectrum are characteristics of kaolinite and $\mathrm{OH}$ deformation linked to $2 \mathrm{Al}^{3+}$, respectively, but they disappeared after sintering. The bands at around $1031,1006 \mathrm{~cm}^{-1}$ and $1043 \mathrm{~cm}^{-1}$ are associated to the $\mathrm{Si}-\mathrm{O}$ stretching mode, and those at 468 and $429 \mathrm{~cm}^{-1}$ and $470 \mathrm{~cm}^{-1}$ are assigned to the $\mathrm{Si}-\mathrm{O}-\mathrm{Si}$ bending vibrations. $\mathrm{Fe}-\mathrm{O}, \mathrm{Fe}_{2} \mathrm{O}_{3}$ and $\mathrm{Si}-\mathrm{O}-\mathrm{Al}$ functional groups were found at 537 and $550 \mathrm{~cm}^{-1}$, while Si-O stretching vibrations of quartz were observed at 796 and $694 \mathrm{~cm}^{-1}$ $(17,18,19)$. Such results are in accordance with EDX and XRD data in Table 1 and Fig. 2, respectively.

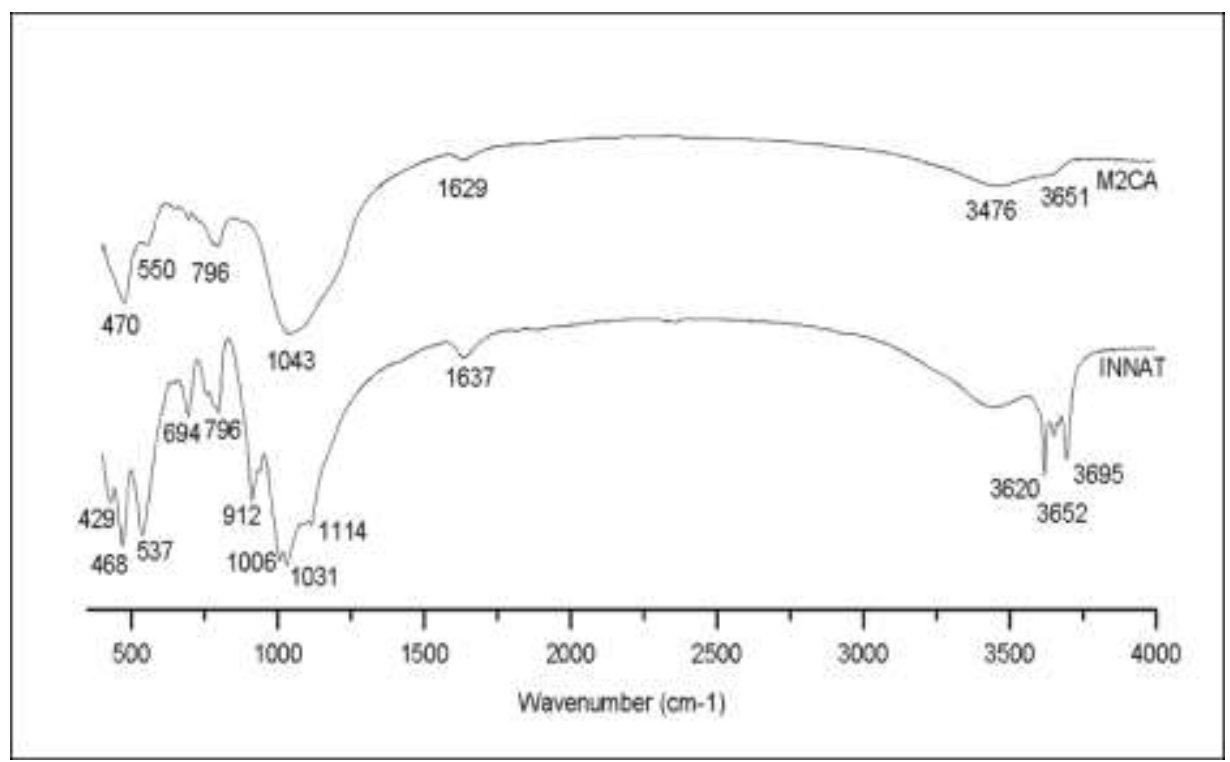

Figure 3:- FTIR spectra of INNAT and M2CA samples. 
Table 2:- FTIR band positions (wavenumber in $\mathrm{cm}^{-1}$ ) and respective bond vibrations for INNAT and M2CA samples.

\begin{tabular}{|c|c|c|c|c|c|c|c|c|}
\hline \multirow[t]{2}{*}{ Sample } & \multicolumn{8}{|c|}{ Band vibrations } \\
\hline & $\begin{array}{c}\mathrm{Al}-\mathrm{OH} \\
\text { stretching }\end{array}$ & $\begin{array}{l}\mathrm{H}-\mathrm{O}-\mathrm{H} \\
\text { bending } \\
\text { of } \mathrm{H}_{2} \mathrm{O}\end{array}$ & Kaolinite & $\begin{array}{c}\mathrm{OH} \\
\text { deformation } \\
\text { linked to } 2 \mathrm{Al}^{3+}\end{array}$ & $\begin{array}{c}\mathrm{Si}-\mathrm{O} \\
\text { stretching }\end{array}$ & $\begin{array}{l}\text { Si-O-Si } \\
\text { bending }\end{array}$ & $\begin{array}{c}\mathrm{Fe}-\mathrm{O}, \\
\mathrm{Fe}_{2} \mathrm{O}_{3} \\
\text { Si-O-Al } \\
\text { stretching }\end{array}$ & $\begin{array}{c}\text { Si-O } \\
\text { quartz }\end{array}$ \\
\hline INNAT & $\begin{array}{l}3695, \\
3652, \\
3620\end{array}$ & 1637 & 1114 & 912 & $\begin{array}{l}1031, \\
1006\end{array}$ & 468,429 & 537 & $\begin{array}{l}796 \\
694\end{array}$ \\
\hline M2CA & $\begin{array}{l}3651, \\
3476\end{array}$ & 1629 & - & - & 1043 & 470 & 550 & 796 \\
\hline
\end{tabular}

Release of benzaldehyde analysis

Figure 4 presents the FTIR spectra of the samples submitted to release assay, recorded in the range $3250-1500 \mathrm{~cm}^{-1}$. The band at about $1696 \mathrm{~cm}^{-1}$ corresponds to the stretching $\mathrm{C}=\mathrm{O}$ of carbonyl group, that identifies the presence of benzaldehyde $(19,29)$. The reduction of this band can be associated to slow release of the benzaldehyde, which reduces the frequency of carbonyl adsorption (21). During the sixty days of assays, it is possible to observe the reduction of this band over time and no benzaldehyde content at the end of the assay. Furthermore, there is a reduction in the bands around the $2750-2500 \mathrm{~cm}^{-1}$ region that corresponds at stretch $\mathrm{C}-\mathrm{H}$ (20), confirming the presence of aldehyde in the pellets. The presence of these bands is associated to benzaldehyde. The band around $3073 \mathrm{~cm}^{-1}$ corresponding to stretching $\mathrm{C}-\mathrm{H}$ can be associated to acid benzoic formation (22), since benzaldehyde tends to transform by partial oxidation to benzoic acid (23). The band observed at about $1640 \mathrm{~cm}^{-1}$ is assigned to illite phase (24) present in the M2CA sample, which was also identified in the XRD diffractogram, Fig. 2.

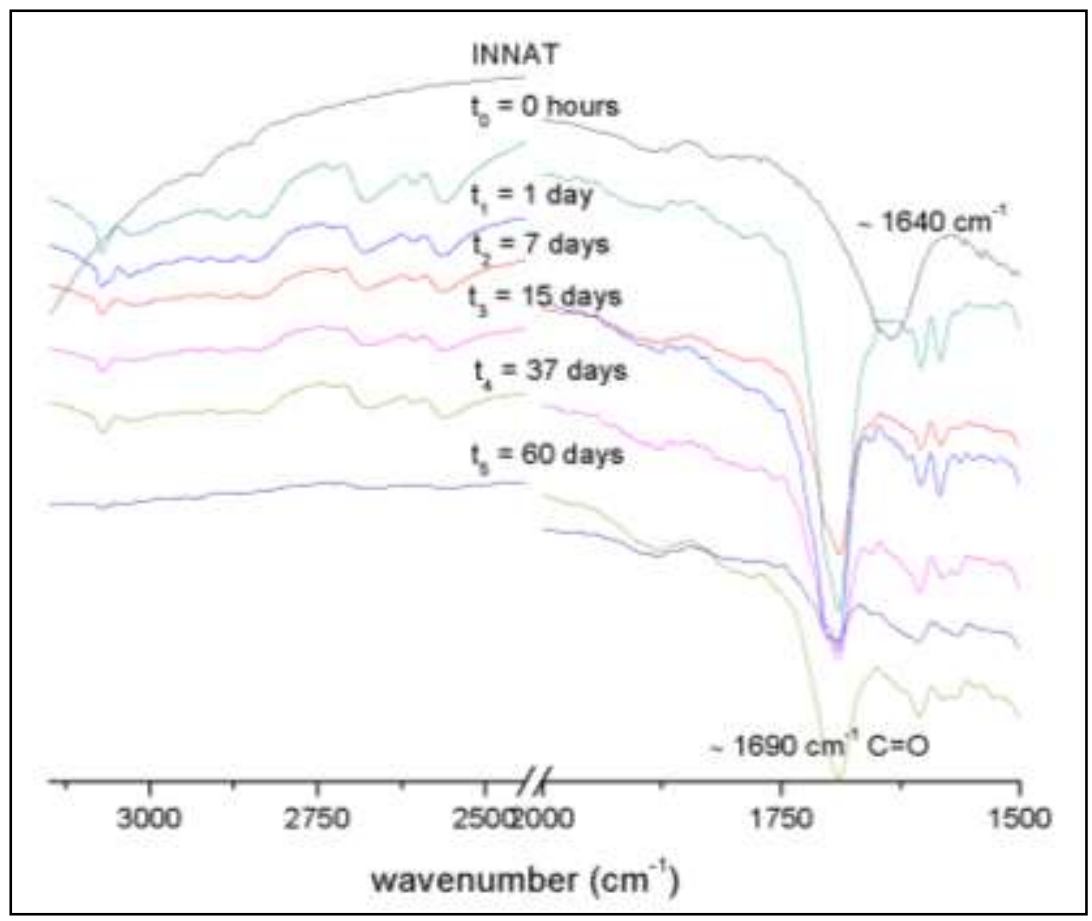

Figure 4:- FTIR spectra of INNAT and M2CA samples in different times of benzaldehyde.

\section{Bioassays Release}

Figure 3 shows the bioassay results obtained from pheromone release M2CA samples with 34 and 100 days of testing. From these data, it can be observed the effectiveness of porous kaolinite pellets in pheromone release. During the tests at different times, it was possible to register catches of triatomine in traps with impregnated pellets (benzaldehyde) and no catch in traps with non-impregnated pellets (control). Considering the effect of the benzaldehyde release by the pellets with respect to triatomine adults of $T$. infestans, female and male, it was 
observed that females were more attracted (41.67\%) than males $(33.33 \%)$. These results are in agreement with the literature $(25,26)$, which report that the triatomine female is more susceptible to the action of the benzaldehyde (12). However, with regard to the nymph instars in comparison with adults, the results were not significant in view of the low percentage $(8.33 \%)$ recorded compared with those obtained for the adult insects. In fact, this result was expected since benzaldehyde is considered a volatile sexual attractant (24). Due to the low index of catches of the nymphs, the assays of 100 days for them were not realized.

In some studies benzaldehyde is also considered as aggregation pheromone (10). However, during these assays aggregation phenomenon was not observed in the impregnated pellets. However, from the bioassays, it was possible to verify a sexual attractant, since the satisfactory results were provided for males and females, but not so for nymph instars.

Bioassays showed that the porous pellets kaolinite is a promising alternative for the implementation of slow release systems for traps in monitoring $T$. infestans systems. It is expected that the pellets can replace the polyethylene vials and reduce costs in potential surveillance tools of Chagas disease vectors (13). It is noteworthy that the highest percentage of capture occurred during the first 60 days of the test, which corroborates the results observed in the release assays of benzaldehyde. The results, Fig. 4, show that after 60 days of this testing, the percentage of benzaldehyde is almost non-existent.

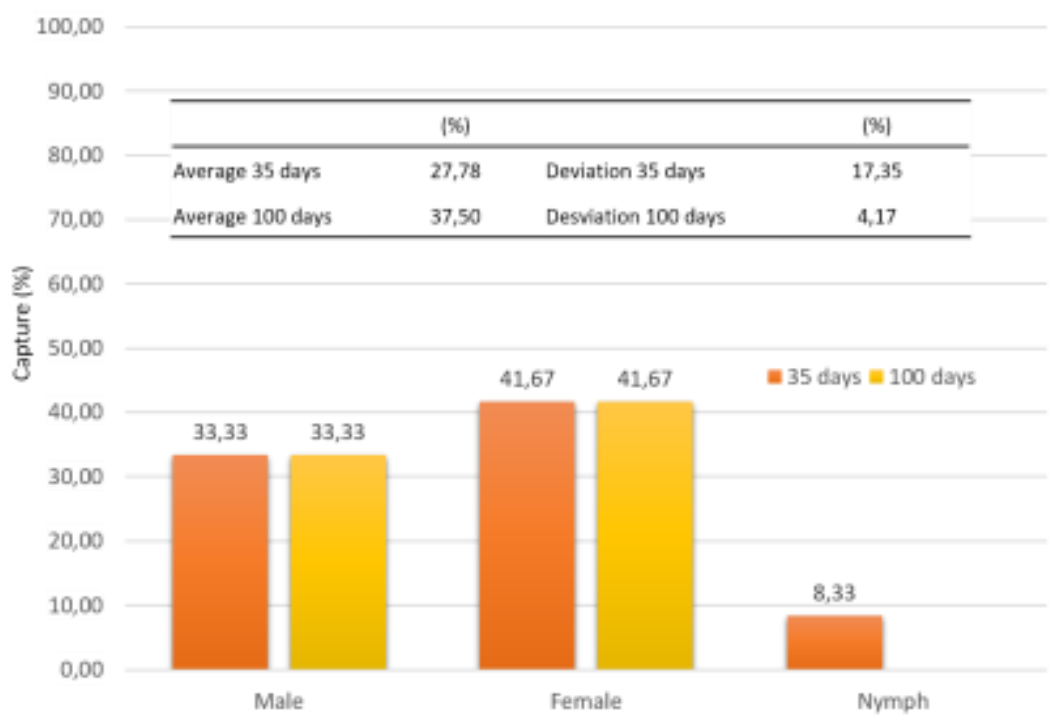

Figure 5:- Bioassay results regarding different sex and nymph instars insects.

According to the results, Fig. 5, the average catch of $T$. infestans, without differentiation between sex and stage, was $27.78 \%$ (35 days) and $37.50 \%$ (100 days). Associating each mean, the standard deviation was $17.35 \%$ and $4.17 \%$ in the cases of 35 and 100 days, respectively. The high value of standard deviation for the capture from 35 days of release can be explained by the low catch of nymphs and due to the reduction of the benzaldehyde effect, from 60 days.

\section{Conclusions:-}

This paper presents a theoretical-experimental analysis of porous kaolinite granules for use as a slow release system of pheromone (benzaldehyde), to attract $T$. infestans. The results show that using the proposed system it is possible to improve the efficiency and reduce the intervals of change of vials when compared to the system of classic polyethylene bags currently used in vector control in the different countries of the region of South America.

The characterization of the kaolinite as raw material showed that the results of the chemical composition did not present contaminants that could react with the benzaldehyde in the pellets o vials. There were no chemical transformations that could compromise the efficiency of work. The results obtained in this work by FTIR does not 
accurately state the relationship between the adsorption and release of benzaldehyde from vials produced from kaolinite. More precise studies, using more appropriate techniques, such as gas chromatography, should be performed to verify the presence of the benzaldehyde in vials at different times.

From the bioassays, it was verified that the porous kaolinite granules are an alternative to be used as slow release systems of benzaldehyde in the traps to attract $T$. infestans, making it possible to reduce the expenses, increasing the potential use in systems of surveillance of vectors of Chagas' disease.

\section{Acknowledgements:-}

The authors thank the PROCIENCIA/Conacyt program funding the 14-INV-037 project and the X-ray Laboratory at the Federal University of Ceará.

\section{Reference:-}

1. Akasay I.A., D.M. Dabbs, and M. Sarikaya. 1991. Mullite for structural, electronic, and optical applications. J. Am. Ceram. Soc. 74:10:2343-58.

2. Ibrahim H.S., T.S. Jamil, and E.Z. Hegazy. 2010. Application of zeolite prepared from Egyptian kaolin for the removal of heavy metals: II. Isotherm models. J. Hazard. Mater. 182:842-7.

3. Ptáček P., Lang K., Šoukal F., Opravil T., Tverdík L., and Novotný R. 2014. Preparation and properties of nanostructured ceramic foam from kaolinite. Powder Tech. 253:29-34.

4. Duarte-Silva R., M.A. Villa-García, M. Rendueles, M. Díaz. 2014. Structural, textural and protein adsorption properties of kaolinite and surface modified kolinite adsorbents. Appl. Clay Sci. 90;73-80.

5. He M.C., J. Zhao, S.X. Wang. 2013. Adsorption and diffusion of $\mathrm{Pb}(\mathrm{II})$ on the kaolinite (001) surface: a density-functional theory study. Appl Clay Sci. 85;74-79.

6. Jin X., M. Jiang, J. Du, Z. Chen. 2014. Removal of $\mathrm{Cr}(\mathrm{VI})$ from aqueous solution by surfactant-modified kaolinite. J Ind Eng Chem. 20:5:3025-32.

7. Priscila F.S., M.M. Zuy, A.L.S.R. Marco, G. T. Letícia, M.P. Rísia, R.M.V. Paulo. 2013. Study of chemical and thermal treatment of kaolinite and its influence on the removal of contaminants from mining effluents. $\mathrm{J}$ Environ Manage. 128:480-8.

8. Murray H.H., 2007. Applied clay mineralogy: occurrences, processing and application of kaolins, bentonites, palygorskite-sepiolite, and common clays. $1^{\text {st }}$ Edition, Elsevier, UK, chapter 2, 7-33.

9. Rajoriya R.K., B. Prasad, I.M. Mishra, K.L. Wasewar. 2007. Adsorption of benzaldehyde on granular activated carbon: kinetics, equilibrium, and thermodynamic. Chem Biochem Eng Q, 21:3:219-226.

10. Torto B., D. Obeng-Ofori, P.E.N. Njari, A. Hassanali, H. Amiani. 1994. Aggregation pheromone system of adult gregarious desert locust Schistocerca gregaria (Forskal). J of Chem Ecol. 20:7:1749-62.

11. Leal W.S., Y. Nacano, Y. Kuwahara, H. Nakao, T. Suzuki. 1988. Pheromone study of acarid mites XVII. Identification of 2-hydroxy-6-methyl-benzaldehyde as the alarm pheromone of the acarid mite Tyrophagus perniciosus (acarina:acaride), and its distribution among related mites. Appl Ent Zool, 23:4:422-7.

12. Fontan A., A.P. González, A. Martinez, R.A. Alzogaray, E.N. Zerba, E. N., F. Camps et al. 2002. Attractant volatiles released by female and male Triatoma infestans (Hemiptera: Reduviidae), a vector of Chagas disease: chemical analysis and behavioral bioassay. Journal of Medical Entomology. 39:1: 191-197.

13. Rojas De Arias A., F. Abad-Franch, N. Acosta, E. López, N. González, E. Zerba et al. 2012. Post-control survaillance of triatoma infestans and Triatoma sordia with chemically-baited sticky traps. Plos Negl Trop Dis. 6:9:1822.

14. Silvia, A. 2012. Procesamiento y producción de pastillas porosas para la lenta liberación de feromonas. Tesis de Maestría. Facultad Politécnica -UNA, San Lorenzo. Paraguay.

15. Herbillon, A. J., M.M. Mestdagh, L. Vielvoye, E.G. Derouane. 1976. Iron in kaolin with special reference to kaolin from tropical soils. Clay Minerals. 11: 3: 20-220.

16. McConville C.J., W.E. Lee. 2005. Microstructural development on firing illite and smectite clays compared with that kaolinite. J Am Ceram Soc. 88:2267-76.

17. Saikia, B. J. and G. Parthasarathy. 2010. Fourier transform infrared spectroscopic characterization of kaolinite from Assam and Meghalaya, Northeastern India. Journal of Modern Physics. 1:4: 206-210.

18. Ilić, B. R., A.A. Mitrović, L.R. Miličić, 2010. Thermal Treatment of kaolin clay to obtain metakaoline, Hem. Ind. 64:4:351-356. 
19. Yuan P, F. Annabi-Bergaya, Q. Tao, M. Fan, Z. Liu, J. Zhu, et al. 2008. A combination study by XRD, FTIR, TG and HRTEM on the structure of delaminated Fe-intercalated/pillared clay. Jour. of Coll. And Interf. Science. 324:142-149.

20. Svedberg, U. 2004. Fourier transform infrared spectroscopy in industrial hygiene application. Acta Universitatis Upsaliensis, Uppsala.

21. Silverstein, R.M., F.X. Webster, D.J. Kiemle. Spectrometric Identification of organic compounds. $7^{\text {th }}$ edition, John Wiley and Sons Inc. New York.

22. Stepania, S.G., I.D. Reva, E.D. Radchenko and G.G. Sheina. 1996. Infrared spectra of benzoic acid monomers and dimers in argon matrix. Vibrational Spectroscopy. 11, 123-133.

23. Gallego, M.M.R. and C.V. Fernández. 2006. Laboratorio de química orgánica. Ed. Universiaria Ramón Areces. Madrid.

24. Oinuma, K and H. Hayashi. 1965. Infrared study of mixed-layer clay minerals. AM Mineral. 50: 1213-1227.

25. Jose A.C.C., T.W. Christopher, D.A. Michael. 2011. ATR-IR study of the adsorption of 2'hydroxyacetophenone and benzaldehyde on MgO. Catalysis Communications. 16:198-204.

26. Cruz-López L., E.A. Malo, J.C. Rojas. 1993. Aggregation pheromone in five species of Triatominae (Hemiptera: Reduviidae). Mem Inst Oswaldo Cruz. 88:535-539. 